\title{
CONCEPTUAL REVIEW ON RELIGIOSITY, WORK-LIFE BALANCE (WLB) AND EMPLOYEE PERFORMANCE IN THE HIGHER EDUCATION INSTITUTIONS (HEIs)
}

\author{
Dr. Mokana A/P Muthu Kumarasamy \\ Faculty of Business and Accountancy \\ Universiti Selangor (UNISEL), Shah Alam, Malaysia \\ E-mail:mokana@unisel.edu.my \\ Farhana Hasbolah \\ Faculty of Business and Accountancy \\ Universiti Selangor (UNISEL), Shah Alam, Malaysia \\ Hanissah Hamzah \\ Faculty of Business and Accountancy \\ Universiti Selangor (UNISEL), Shah Alam, Malaysia \\ Khairun Natasha Mohd Fazmi \\ Faculty of Business and Accountancy \\ Universiti Selangor (UNISEL), Shah Alam, Malaysia \\ Siti Aisyah Omar \\ Faculty of Business and Accountancy \\ Universiti Selangor (UNISEL), Shah Alam, Malaysia \\ Dr. Abul Bashar Bhuiyan \\ Faculty of Business and Accountancy \\ Universiti Selangor (UNISEL), Shah Alam, Malaysia
}

Received: August 28, $2021 \quad$ Accepted: September 29, $2021 \quad$ Online Published: November 29, 2021

DOI: 10.46281/aijssr.v10i1.1469

URL: https://doi.org/10.46281/aijssr.v10i1.1469

\begin{abstract}
Working from home (WFH) is now becoming a new normal, and today it brings a big change in the way people think and act. However, some people find that working from home is a big challenge, especially for those with families and young children. This is not easy and it leads to stress and burdens because the employees were not able to share a good time with their family and work demands. This study aims to identify the influencing factors of Work-life balance (WLB) on employee performance and moderating effect of religiosity towards WLB and employee performance of HEIs. The study will be used to accumulate empirical literature by the name of religiosity towards WLB and employee performance in different online database
\end{abstract}


sources. The review findings show that there is a significant effect of WLB especially, technological, institutional, and individual factors are considered the most influential effects on employee performance. This study also identified that there is a moderating effect of religiosity towards WLB and employee performance of HEIs. The findings will be used to develop a reach framework and will be conducted a rigorous depth study and will be drawn policy guidelines for further improvement of WLB and employee performance in HEIs.

Keywords: Work-life Balance (WLB), Employee Performance, Religiosity.

\section{INTRODUCTION}

Work-life balance (WLB), which concerns the quality of life, has become an important issue to employees and employers in the era of globalization (Hilbrecht, Shaw, Johnson \& Andrey, 2008). The WLB of employees can improve organizational performance and individual performance. Following the COVID-19 pandemic that has hit the world now, the Malaysian Government has implemented the Movement Control Order (MCO) period which affected various sectors and industries. Besides, it has changed the way people and lifestyles, such as the work culture in the office where many employees are instructed to work from home to curb the epidemic transmission of the virus. With help from technological advances, allowed individuals to work anytime, anywhere, and non-stop. The recent and future work trends that have shifted to automation technology have resulted in longer working hours. This idea is an idea that arose in line with the development of the industrial revolution 4.0 where technology is used as best as possible in communication. Working from home or WFH is now becomes a new normal bring a major change in human thought and action today. This situation demands efficient remote tasks, availability of appropriate facilities and equipment, time management, and the integrity of each individual.

In general, working from home has various advantages such as flexible time, a quiet workspace environment, a better balance between home and office, more effective implementation, and no need to get involved in traffic congestion. However, some individuals feel that working from home is very challenging, especially for individuals with families and having small children. The challenge is certainly greater than it can create stress due to the need to fulfil various responsibilities simultaneously such as taking care of the household and children and at the same time also need to perform tasks from the employer. This is not easy and it leads to stress and burdened as employees were not able to divide good time with their families and job demands (Mat Yusof, Rizuan, Azidin, Abdul Latif \& Ismail, 2014). When they are unable to spend more time together with family then all dissatisfaction will be released at work and will give an impact on the quality of work. A study done by Yadav and Rani (2015) found that employees who were satisfied and happy with a good work environment as well as being able to spend time with family tend to perform better and give the best against institutions (Yadav \& Rani 2015).

Balancing work and family demands is the hardest thing to do in life. The ability of an individual to enjoy the four aspects of his life namely career, family, friends, and self is subjective. Each individual has different needs and it is the individual himself who knows how to place priorities in life so that balance can be achieved. According to Greenhaus, Collins and Shaw (2003), work and life balance are defined as the state of an individual who is tied to a balance between his role and responsibility towards work and life and is satisfied with it. A study by Hyoung (2014) suggested that a well-found career-family balance among employees is a 
major pillar in achieving job satisfaction and improve the performance of an organization. In other words, career-family balance is also possible to increase self-motivation and so on contributes to the high performance of employees. Achieving work and family balance occurs when individuals allocate mental, physical, and emotional resources in ways that can meet personal and professional goals. It has to do with the capacity among employees to manage their job tasks, coordinate these tasks with co-workers, and take responsibility for the success or failure of these tasks (Hjort, Hoyer, Bramming \& Pedersen, 2011). This is important to avoid the emergence of guilt in oneself as well as to create conflict.

In the context of COVID-19, the organization may have difficulty in supervising and monitoring its employees but the only available option is WFH. A study by Susilo (2020) in Indonesia revealed that WFH increased the employees' enjoyment and job satisfaction but it will depend on the industry. Hence, this study will select different industry for instance higher education institutions in Malaysia (HEIs). There are a lot of factors that influencing WLB such as individual and institutional factors. Therefore, this study will focus on technology factors, individual factors, institutional factors, and religiosity that will contribute to the balance between work and life in HEIs.

\section{Work-life Balance}

\section{EMPIRICAL REVIEW FINDINGS}

WLB, which concerns the quality of life, has become an important issue to employees and employers in the era of globalization (Hilbrecht, Shaw, Johnson \& Andrey, 2008). In the past year, employees dedicated and devoted most of their time at work leaving them feels overwhelmed in balancing their role between family and social life in this competitive work setting. The ability of an individual to balance these three factors can be defined as work-life balance (WLB).

Initially, the WLB concept was to study women who wear multiple hats as well as family conflict (Kahn, Wolfe, Quinn, Snoek \& Rosenthal, 1964) although it is now expanded to both genders. WLB has a broad concept as the definition and dimension of WLB are different based on each researcher. WLB is described as the tendency for a person to become fully engaged in the performance of every role in one's overall system, with the approach to each role and role partner with attentive and care (Marks \& Mac Dermid,1996). It is defined as an achievement in all life aspects as all resources such as energy, time, and commitment are well distributed across all aspects (Kirchmeyer, 2000). It is supported by Hill, Hawkins, Ferris, and Weitzman (2001) definition that WFH is the ability to which a person can concurrently balance demands from paid work, personal, and family in response to behavioural, emotional, and time aspects.

Many past studies discover that a person can be involved in multiple domains and is not only based on work and home domains alone. Warren (2004) identified over 170 different life domains based on the previous studies. Among domains that individuals can be participated in are domains of work, leisure, neighbourhood, family, friendships, social involvement, and health. These domains have been observed and are intertwined or rather closely related to gives an imbalance impact towards a person life shall not control effectively.

\section{Higher Education Institutions (HEIs)}

Education plays a significant role in the development of any country, including Malaysia. Thus, the education system was designed through the establishment of schools, colleges, and universities. Higher Education Institutions (HEIs) in Malaysia begins in 1959 with the 
establishment of the University Malaya (UM). As of 2021, the number of public universities in Malaysia is 20, and more than 437 private higher education was established in Malaysia (MOHE, 2021). All programs offered by HEIs must receive accreditation from Malaysia Qualifications Agency (MQA).

The academic staff is the key resource both in public and private HEIs. Below are the total academic staffs for both institutions as of 2019.

Table 1. Total academic staff for both institutions as at 2019

\begin{tabular}{|l|c|c|}
\hline Number of Academic Staff According by positions & Public & Private \\
\hline Professors & 1,945 & 601 \\
\hline Associate Professors & 4,753 & 1,006 \\
\hline Lecturers & 22,502 & 19,278 \\
\hline Language Teachers & 1,206 & 0 \\
\hline $\begin{array}{l}\text { Other Academic Staffs Including Research Fellow, Industrial } \\
\text { Fellow, Vocational Officer, Assistant Lecturer, Teacher, } \\
\text { Assistant Teacher, Post-Doctoral and other academic staffs }\end{array}$ & 1,220 & 5,076 \\
\hline
\end{tabular}

Source: MOHE, 2019.

The number of academic staff above represents the number of university lecturers in Malaysia. The position of academic staff can be recognized based on higher education levels such as $\mathrm{PhD}$, masters, and degree. It is further supported by the research activities through their publication in reputable journals. Meanwhile, the responsibilities of lecturers today are continuously challenging as not only focus on teaching but writing, supervising, monitoring the students, and some clerical works.

\section{Technology Factors and Employee Performance}

Appropriate identification of research participants is critical to the science and practice of psychology, particularly for generalizing the findings, making comparisons across replications, and using the evidence in research syntheses and secondary data analyses. If humans participated in the study, report the eligibility and exclusion criteria, including any restrictions based on demographic characteristics. Technology advancement has been defined in different ways. For instance, Makinson, Hundley, Feldhaus, and Fernandez (2012) defined that a technology advancement is a tool that has transformed work from a place you go to a function you perform, whenever and wherever you happen to be when a call, email, or social networking device reveals the next urgent assignment.

According to Stawarz, Cox, Bird, and Benedyk (2013), advances in technology, in particular, the widespread use of mobile devices, have changed work practices and transformed our everyday lives. Information technology has vital importance and providing maximum services to every field. There is the momentous influence of technology in every field such as from educational institutions to the automobile industry, banking to civil aviation, telecom to textile (Abbas, Muzaffar, Mahmood, Ramzan \& Rizvi, 2014). To sustain and meet customer needs, organizations have to adopt new practices and new technologies by modifying the traditional way of doing work. Therefore, organizations motivate the employees to adopt the new technology to the employee for better performance (Dauda \& Akingabede, 2011) as well as less the employee working effort and task completion time. 
The development of technology has an impact on firm performance (Mumford, 2000). According to Huang, Lee, Chiu, and Yen (2015) technology advancement also plays a key role in setting up the performance of employees. Another author also found that technological advancement has an enormous influence on employee performance in the banking sector (Imran, Maqbool \& Shafidue, 2014). Most studies have repeatedly shown a positive relationship between a firm's technological advancement and performance and concluded that technological advancement is important for employee performance (Abbas et al, 2014).

\section{Individual Factors and Employee Performance}

Infectious disease risks such as COVID-19 must be understood as part of the workplace as people now live and work in internationally interdependent populations (Narayanan, Anseel, Antonakis, Ashford, Bakker, \& Vugt, 2021). Employees are not only faced with a high job demand during the COVID-19 pandemic, but they must also organize their personal lives. These factors have contributed to the deterioration of their WLB, which has harmed their mental health. A report by International Labour Organization (2020) suggested that increased flexibility in working-time arrangements, it will allow the employee to meet their duties and responsibilities.

The importance of WLB is how the employee's performance in fulfilling their responsibilities and commitment at the home, workplace, and in other aspects of life. The effective relationship between employee and organization was determined by the working employee's performance at the workplace. The equilibrium in WLB is where the participation from employees and organization are equal. Employees' performance at work and in their personal lives is therefore influenced by a lack of WLB, while the employee who has a stronger WLB will contribute more significantly to the organization's growth and success (Alhazemi \& Ali, 2016). A study by Bjarntoft, Hallman, Mathiassen, Larsson and Jahnke (2020) classified the individual factors into over-commitment, overtime work, and boundary management. They have found that all these factors were associated with WLB among office workers subject to flexible work arrangements. Vyas and Shrivastava (2017) develop a conceptual model of the factors affecting WLB. In this study, the authors found that social support, organizational factors, stress factors, information technology factors are the vital factors that affect the WLB of an individual. Meanwhile, Rafikah (2020) found that emotional intelligence has no significant effects on the WLB of an individual but it has a positive effect on the job performance of an employee.

\section{Institutional Factors and Employee Performance}

The institutional factor is considered as one of the biggest influences for the worker to achieve a WLB. There is an increasing amount of research has been done relating to many aspects of organizational support in terms of work support, flexible work arrangement, job stress, and WLB policies and programs.

Many studies have been done on work support concerning WLB. Previous studies show that supervisors can exert considerable influence and impact over employees' WLB and worklife practices (McCarthy, Darcy, \& Grady, 2010; Fiksenbaum, 2013; Au \& Ahmed, 2016). Research on supervisor support and WLB shows that a supportive supervisor displays a positive significant impact on employee emotional support and helps in maintaining a WLB of employees in the Australian financial sector (Talukder, Vickers \& Khan, 2018). Organizational supports offered in a workplace can be varied in terms of empathy, accommodating, and the ability to listen to employees. It is reported that through support, employees' psychological and 
environmental conditions can make employees feel safer and more capable to invest in activities that promote greater WLB.

The flexibility of work is synonym with the flexible working arrangement (FWA) (Shagvaliyeva \& Yazdanifard 2014). Work flexibility is defined as the ability of workers to control the duration of their good work from any location based on the schedule that has been given by the organization (Atkinson \& Hall, 2011). Past studies discover and highlighted that flexible work arrangements would help the employees to be able to adjust and arrange between work and non-work activities thus motivate their employees (Russo, Shteigman, \& Carmeli, 2016) It is supported by the research done by Capnary, Rachmawati, and Agung, (2018) discovers that through the flexibility of work arrangement, it can influence WLB of employee and positively affected employee's loyalty to the Indonesian start-up companies. WLB through offering a flexible work schedule enables employees to accomplish work and non-work commitments and responsibilities.

\section{Religiosity and Employee Performance}

Ferm (1963) contended that an acceptable definition of religion refers to "a set of behaviours or meanings which are connected to the action of a religious person". According to Al-Goaib (2003), in Islam, religiosity is the commitment to the fundamentals of Islamic religion empirically and theoretically through the fulfilment of Allah's rights, the protection of others' rights, following Allah"s orders, avoiding bad acts, and performing worship.

Individuals characterized as religious are not only those who hold particular religious beliefs but also practice them in day-to-day life (Morgan \& Lawton, 1996). It is suggested that people who hold and follow certain religious dogmas will exhibit particular sets of behaviours that are reflected in their personal and social lives. It is thus likely that employees' work behaviour will also be affected by their religious preferences to the extent to which they identify themselves with and are active followers of a certain religion (Ntalianis \& Darr, 2005).

Vasconcelos (2010) indicated that religion is a pervasive subject that influences somewhat employees' behaviours, perceptions, and decisions of individuals. McCarty (2007) also remarked that the participants had reported very interesting results from these prayer meetings, such as increased employee morale and productivity, and decreased employee turnover. Highly religious employees were unlikely to cheat whether or not they had taken a business ethics course, employees who were not highly religious demonstrated less cheating if they had taken a business ethics course. In other words, highly intelligent individuals displayed significantly less cheating if they were highly religious.

Employee religious values can serve as personal resources are very important to maintain or protect themselves from the emergence of a sense of anxiety-related jobs. When the level of the employee's religious values is high, then a sense of anxiety-related job be reduced, which has positive consequences for the performance of their duties (De Cieri, Holmes, Abbott, \& Pettit, 2005). Religious values are capable of providing guidance, encouragement, and support to employees in completing their best performance. Furthermore, religious individuals tend to have pro-social beliefs and engage in totality in the conduct of social pro-than individuals who do not have religious values (McGraw, Putnam, \& Campbell, 2012). It is also supported by some research (Darto, Setyadi, Riadi, \& Hariyadi, 2015; Zahrah, Hamid, Rani, \& Kamil, 2016), which also found that having a significant influence on the performance of employees. 
However, the results of the above research findings with contradictory Osman-Gani, Hashim, and Ismail (2013), found that religious values are not significant effect on the performance of employees. This is caused by the lack of realization of religious values (such as the activities of prayer) and employee morale so that they are not capable of showing the best performance. Ozbilgin, Beauregard, Tatli, and Bell (2011), and Boyce (2006) argued, 'religion does not feature as the major influence in the way the work-life interface is organized in contemporary societies'.

Apart from this, some of the research conducted religiosity as a moderator. Religiosity can moderate the relationships between job demands and work-to-life conflict, and work hours and work-to-life conflict, but not between work flexibility and work/life facilitation, and family demands and life-to-work conflict (Sav, 2019). Given the existence of inconsistent findings from some researchers, this study elaborates on the relationship between religiosity and the performance of employees.

\section{WLB, COVID-19, and Higher Education Institutions (HEIs)}

The world health crisis has affected many countries including Malaysia to implement MCO to curb the spread of the virus. The impacts caused by the pandemic crisis are very huge, bringing about major changes in the field of education. Based on data obtained from United Nations Educational, Scientific and Cultural Organization (UNESCO), 990,324,537 students were affected by this pandemic. For the past year, many of the employees, including academic staff have worked from home, provide online learning to students, made countless work and social calls, and have struggled to maintain composure in to face of uncertainty of the endless pandemic. Academic staff struggle to balance their time for family and complete office work such as lecture planning, research preparation, checking and assessing students' work, attending staff meetings, supervising students, writing research proposals, papers, and other publications. All these responsibilities that burden the academic staff will cause stress and tension to the psychology, physiology, and behaviour. At the same time, the pandemic crisis has urged them to change their views on how they can carry out their respective jobs in the new norms.

WFH itself is one of the solutions for coping with work stress (Sullivan \& Lewis, 2001). The concept of working from home is not a new phenomenon. It is a form of flexible work arrangement that can reduce the operating costs of the organization and increase job satisfaction especially among working women with families. Employees who are working from home tend to have higher motivation as compared to employees who are working from the office (Rupietta \& Beckmann, 2018). Sullivan (2000) stated that working from home increase boundary flexibility between the work domain and the family domain. Basu, Karmakar, Bidhan, Kumar, Brar, Pandit, and N.Latha (2020) explained that the company's support in providing flexible working hours especially during the COVID-19 situation can protect the employees' mental health. Employers should take the initiative in providing a WLB and ensure the employees' productivity. WLB is one of the factors that can help employees to improve the quality of mental health and reduce stress (Laker, 2020) while increasing individual self-resistance so that they can make decisions more efficiently and effectively.

\section{CONCLUSION}

WLB is even less achievable, as working from home eliminated the boundaries between the time that should be dedicated to working and the time that should be reserved for oneself. Gadecki, Jewdokimow, and Żadkowska (2018) in their writing mentioned that working from home often causes conflict in the WLB because there will be conflicts of interest that which one should come 
first. While employees have good quality times gatherings with family members, they need to complete the office works at the same time. Today's technology and industrial revolution 4.0 has introduced various online applications which allow employees to complete their jobs within stipulated times, easily, quickly, and efficiently. A stable internet network, laptop, or mobile phone are the most important gadgets for employees to perform tasks anywhere and anytime when they are working from home. Dependence on this technology has become a further burden on the employees, which leads to technostress, namely feelings of anxiety, fatigue, scepticism, and hopeless beliefs related to the use of technology (Salanova, Llorens, \& Cifre, 2013).

The era of the industrial revolution 4.0 is an absolute and unavoidable phenomenon. This technology has been widely applied by various employment sectors such as private and public organizations, including the education sector. Meeting activities, discussions, consultations, division of tasks, teaching, and learning can be conducted just by being at home. The implementation of $\mathrm{MCO}$ and the uncertainty of the world health crisis has posed a great challenge to higher education institutions in ensuring the continuity of the learning process. The management is obliged to strategize and take practical steps that can ensure the sustainability of the institutions. Among the strategies that are crucial to pay attention to is readiness for change in each organization, especially in global-oriented educational organizations (Fayzhall, Purwanto, Asbari, Basuki, Mustofa, Hutagalung, Maesaroh, Winanti, Chidir, Goestjahjanti, \& Andriyani, 2020; Jumiran, Novitasari, Nugroho, Sutardi, Sasono \& Asbari, 2020; Kamar, Novitasari, Asbari, Winanti \& Goestjahjanti, 2019). Simarmata (2020) in his study shows there is a relationship between working from home and the work productivity of academic staff. There are various favourable situations and conditions when teaching and learning activities are conducted online or at home such as a flexible working environment, being closer to family members, no stress disorder, and saving travelling time between the office and home. They feel healthier and can achieve WLB, being able to divide between home affairs and office activities.

Every individual must show high integrity in performing duties and responsibilities. They need to find the best working method to complete their respective tasks. This is where they need to be creative and innovative. For example, online learning and teaching activities can be conducted using a variety of online platforms, while alternative assessment methods continue to be explored. Certainly, the COVID-19 challenges will open up new research possibilities that can benefit the students and institutions. Besides, the transformation of the academic and research activities in the university should be planned to face the new norms of the post-Covid19. In the meantime, good integration between work assignments and daily responsibilities will produce the best outcomes for the academic staff. With full of the uncertainty of COVID-19, it is not an exaggeration that the role of academic staff in universities is no exception but more challenging.

\section{REFERENCES}

Abbas, J., Muzaffar, A., Mahmood, H. K., Ramzan, M. A., \& Rizvi, S. S. U. H. (2014). Impact of Technology on Performance of Employees (A Case Study on Allied Bank Ltd, Pakistan). World Applied Sciences Journal, 29(2), 271-276.

Alhazemi, A., A., \& Ali, W. (2016). The Notion of Work-Life Balance, Determining Factors, Antecedents and Consequences: A Comprehensive Literature Survey. International Journal of Academic Research and Reflection, 4(8), 74-85. 
Al-Goaib, S. (2003). Religiosity and social conformity of university students: an analytical study applied at King Saoud University. Arts Journal of King Saoud University, 16(1), 51-99.

Atkinson, C., \& Hall, L. (2011). Flexible working and happiness in the NHS. Employee Relations, 33(2), 88-105. 10.1108/01425451111096659.

Au, W. C., \& Ahmed, P. K. (2016). Relationships between superior support, work role stressors and work-life experience. Personnel Review, 45(4), 782-803.

Basu, S., Karmakar, A., Bidhan, V., Kumar, H., Brar, K., Pandit, M., \& N.Latha. (2020). Impact of lockdown due to COVID-19 outbreak: lifestyle changes and public health concerns in India. International Journal of Indian Psychology, 8(2), 1385-1411.

Bjarntoft, S., Hallman, D., M., Mathiassen, S., E., Larsson, J., and Jahnke, H. (2020). Occupational and Individual Determinants of WLB among Office Workers with Flexible Work Arrangements. International Journal of Environmental Research and Public Health, 17(4), 1-15.

Capnary, M. C., Rachmawati, R., \& Agung, I. (2018). The influence of flexibility of work to loyalty and employee satisfaction mediated by work-life balance to employees with millennial generation background in Indonesia start-up companies. Business: Theory and Practice, 19(2), 217-227.

Darto, M., Setyadi, D., Riadi, S. S., \& Hariyadi, S. (2015). The effect of transformational leadership, religiosity,job satisfaction, and organizational culture on organizational citizenship behaviour and employee performance in the regional offices of the national institute of public administration, Republic of Indonesia. European Journal of Business and Management, 7(23), 205-219.

Dauda, Y. A., \& Akingbade, W. A. (2011). Technological Change and Employee Performance in Selected Manufacturing Industry in the Lagos State of Nigeria. Australian Journal of Business and Management Research, 1(5), 32-43.

De Cieri, H., Holmes, B., Abbott, J., \& Pettit, T. (2005). Achievements and challenges for work/life balance strategies in Australian organizations. International Journal of Human Resource Management, 16(1), 90-103. DOI: 10.1080/0958519042000295966

Fayzhall, M., Purwanto, A., Asbari, M., Basuki, S., Mustofa, M., Hutagalung, D., Maesaroh, S., Winanti, W., Chidir, G., Goestjahjanti, F., \& Andriyani, Y. (2020). Pengaruh Gaya Kepemimpinan Terhadap Kapabilitas Inovasi Guru Dalam Perspektif Organizational Learning. EduPsyCouns: Journal of Education, Psychology and Counseling, 2(1), 6491.

Ferm, V. (1963). An encyclopaedia of religion, (pp. 647), London: Peter Owen. 
Fiksenbaum, L. M. (2013). Supportive work-family environments: implications for work-family conflict and well-being. The International Journal of Human Resource Management, 25(5), 653-672.

Gadecki, J., Jewdokimow, M., \& Zadkowska, M. (2018). New Technologies and Family Life in The Context of Work at Home. The Strategies of Work-Life Balance. Studia Humanistyczne AGH, 17(4), 77-89.

Greenhaus, J. H., Collins, K. M. \& Shaw, J. D. (2003). The Relation between Work-Family Balance and Quality of Life. Journal of Vocational Behavior, 63(3), 510-531.

Hilbrecht, M., Shaw, S. M., Johnson, L. C., \& Andrey, J. (2008). 'I'm home for the kids': Contradictory implications for the work-life balance of teleworking mothers. Gender, Work and Organization, 15(5), 454-476.

Hill, E., J., Hawkins, A., J., Ferris, M., \& Weitzman, M. (2001). Finding an Extra Day, a Week: The Positive Effect of Job Flexibility on Work and Family Life Balance. Family Relations, 50(1), 49-58.

Hjorth, T. L., Hoyer, M. G., Bramming, P., \& Pedersen, M. (2011). Governing work through self-management. Ephemera Theory and Politics in Organization. 11(2), 97-104.

Huang, S. Y., Lee, C. H., Chui, A. A., \& Yen, D. C. (2015). How Business Process Reengineering affects Information Technology Investment and Employee Performance Under Different Performance Measurement. Information System Frontiers, 17, 1133 1144.

Hyoung, K. H. (2014). Work-Life Balance and Employees' Performance: The Mediating Role of Affective Commitment. Global Business and Management Research: An International Journal 6(1), 37-51.

Imran, M., Maqbool, N., \& Shafique, H. (2014). Impact of Technology Advancement on Employee Performance in Banking Sector. International Journal of Human Studies, 4(1), 57-70.

International Labour Organization. (2020). Managing Work-Related Psychosocial Risks During the COVID-19 Pandemic. ( $1^{\text {st }}$ Ed.). Geneva, Switzerland: ILO Publications.

Jumiran, J., Novitasari, D., Nugroho, Y., Sutardi, D., Sasono, I., \& Asbari, M. (2020). Pengaruh Dimensi Kepemimpinan Transformasional terhadap Kepuasan Kerja dan Komitmen Organisasional: Studi Kasus pada Dosen Perguruan Tinggi Swasta. EduPsyCouns: Journal of Education, Psychology and Counseling, 2(1), 600-621.

Kahn, R., Wolfe, D., M., Quinn, R., P., \& Snoek, J., D. (1964). Organizational Stress: Studies in role conflict and ambiguity. In: Rushing W. A. (Ed), Social Forces, (pp. 591-592), New York: John Wiley \& Sons. 
Kamar, K., Novitasari, D., Asbari, M., Winanti, \& Goestjahjanti, F. S. (2019). Enhancing Employee Performance during the Covid-19 Pandemic: The Role of Readiness for Change Mentality. Jurnal Dinamika Manajemen, 11(2), 154-166.

Kirchmeyer, C. (2000). Work-life initiatives: Greed or benevolence regarding workers' time. In C. L. Cooper \& D. M. Rousseau (Eds.), Trends in organizational behaviour (pp.79-93). West Sussex, UK: Wiley.

Laker, B. (2020). How to Dramatically Improve WLB. Retrieved from https://www.forbes.com/sites/benjaminlaker/2020/04/28/how-to-dramaticallyimprovework-life-balance-during-coronavirus-crisis/?sh=7103295b1e2a.

Latha, S. (2020). Work-Life Balance in Pandemic: A Conceptual Study of Problems and Challenges Faced by Working Women Professionals. Mukt Shabd Journal, IX (V), 61736179.

Makinson, P., Hundley, S., Feldhaus, C., \& Fernandez, E. (2012). Mobile communications anytime, anywhere: The impact on work-life balance and stress. Frontiers in Education Conference Proceeding (pp 1-6). Seattle, USA, October 3-6. IEEE Publishing.

Marks S. R., \& MacDermid, S. M. (1996). Multiple Roles and The Self: A Theory of Role Balance. Journal of Marriage and the Family, 58(2), 417-432.

Mat Yusof, M. R., Ridzuan, N., Azidin, A., Abdul Latif, M. M. R., \& Ismail, I. (2014). The impact of work stress on work-life balance in Malaysia. International Journal of Economics, Commerce and Management 2(11): 4-6.

McCarthy, A., Darcy, C., \& Grady, G. (2010). Work-life balance policy and practise: Understanding line manager attitudes and behaviours. Human Resource Management Review, 20(2), 158-167.

McCarty, W. B. (2007). Prayer in the Workplace: Risks and Strategies to Manage Them. Business Renaissance Quarterly, 2(1), 97-105.

McGraw, B. T., Putnam, R. D., \& Campbell, D. E. (2012). Review of American Grace: How Religion Divides and Unites Us. The Journal of Politics, 74(4), E44.

MOHE. (2019). Kementerian Pendidikan Tinggi Malaysia (MOHE). Statistik Pendidikan Tinggi 2019: Kementerian Pengajian Tinggi. Retrieved from https://www.mohe.gov.my/

MOHE. (2021). Kementerian Pendidikan Tinggi Malaysia (MOHE). Retrieved from https://www.mohe.gov.my/

Morgan, P., \& Lawton C. (Eds.). (1996). Ethical issues in six religious traditions, Edinburgh: Edinburgh University Press. 
Mumford, M. D. (2000). Managing Creative People: Strategies and Tactics for Innovation. Human Resource Management Review, 10(3), 313-351.

Narayanan, M. J., Anseel, F., Antonakis, J., Ashford, S. P., Bakker, A. B., \& Vugt, M. V. (2021). COVID-19 and the Workplace: Implications, Issues, and Insights for Future Research and Action. Kniffin American Psychologist, 76(1), 63-77.

Ntalianis. F., \& Darr, W. (2005). The influence of religiosity and work status on psychological contracts. The International Journal of Organizational Analysis, 13(1), 89-102.

Osman-Gani, A. M., Hashim, J., \& Ismail, Y. (2013). Establishing linkages between religiosity and spirituality on employee performance. Employee Relations, 35(4), 360-376.

Ozbilgin, M. F., Beauregard, T. A., Tatli, A., \& Bell, M. P. (2011). Work-life, diversity and intersectionality: A critical review and research agenda. International Journal of Management Reviews, 13, 177-198. doi:10.1111/j.1468-2370.2010.00291.x

Rafikah, R. (2020). Pengaruh Kecerdasan Emosi Terhadap Employee Performance Melalui WLB Karyawan PT. Hasil Bantuan Cipta Perdana Gresik. Jurnal Ilmu Manajemen, 8(2), 434-442.

Rupietta, K., \& Beckmann, M. (2018). Working from Home. Schmalenbach Business Review, Springer; Schmalenbach-Gesellschaft, 70(1), 25-55.

Russo, M., Shteigman A. \& Carmeli, A. (2016) Workplace and family support and work-life balance: Implications for individual psychological availability and energy at work. The Journal of Positive Psychology, 11(2), 173-188.

Salanova, M., Llorens, S., \& Cifre, E. (2013). The dark side of technologies: Technostress among users of information and communication technologies. International Journal of Psychology, 48(3), 422-436.

Sav, A. (2019). The role of religion in the work-life interface. The International Journal of Human Resource Management, 30(22), 3223-3244.

Shagvaliyeva, S., \& Yazdanifard, R. (2014). Impact of Flexible Working Hours on Work-Life Balance. American Journal of Industrial and Business Management, 4(1), 20-23.

Simarmata, R. M. (2020). Pengaruh Work from Home Terhadap Produktivitas Dosen Politeknik Negeri Ambon. Jurnal Ekonomi, Sosial \& Humaniora, 2(1), 73-82.

Stawarx, K., Cox, A. L., Bird, J., \& Benedyk, R. (2013). I'd Sit at Home and Do Work Emails: How Tablets Affect the Work-Life Balance of Office Workers. Proceedings of the Conference on Human Factors in Computing Systems (CHI EA'13) (pp. 13831388). Paris, France, April 27 - May 2. 
Sullivan, C., \& Lewis, S. (2001). Home-based telework, gender, and the synchronization of work and family: Perspectives of teleworkers and their co-residents. Gender Work and Organization 8(2), 123-145.

Sullivan, O. (2000). The Division of Domestic Labour: Twenty Years of Change? Sociology, $34(3), 437-456$.

Susilo, D. (2020). Revealing the Effect of Work-From-Home on Job Performance during the Covid-19 Crisis: Empirical Evidence from Indonesia. Journal of Contemporary Issues in Business and Government. 26, 23-40.

Talukder, A. K. M., Vickers, M., \& Khan, A. (2018). Supervisor support and work-life balance: Impacts on job performance in the Australian financial sector. Personnel Review 47(3), 727-744.

Vasconcelos, A. F. (2010). The effects of prayer on organizational life: a phenomenological study. Journal of Management and Organization, 16(3), 369-381.

Vyas, A., \& Shrivastava, D. (2017). Factors Affecting Work-Life Balance - A Review. Pacific Business Review International, 9(7), 194-200.

Warren T. (2004) Working part-time: Achieving a successful work-life balance? The British Journal of Sociology, 55(1), 99-122.

Yadav, T., \& Rani, S. (2015). Work-life balance: challenges and opportunities. International Journal of Applied Research, 1(11), 680-684.

Zahrah, N., Hamid, S. N. A., Rani, S. H. A., \& Kamil, B. A. M. (2016). Enhancing Job Performance through Islamic Religiosity and Islamic Work Ethics. International Review of Management and Marketing, 6(7S), 195-198.

\section{Copyrights}

Copyright for this article is retained by the author(s), with first publication rights granted to the journal. This is an open-access article distributed under the terms and conditions of the Creative Commons Attribution license (https://creativecommons.org/licenses/by/4.0) 